\title{
ILMU KOMUNIKASI DI DALAM PENDIDIKAN AGAMA HINDU
}

\author{
Ni Nyoman Ayu Wilantari ${ }^{1}$
}

\begin{abstract}
Since human was born, they were gifted by skill of communication. This skill then develop further everytime, so that the message can be understood by the receiver. By the proces of comunication, there should be message from the giver as known communicator and the receiver as known communicant. Hindu education by using communication knowledge, can be done by anyone and anywhere.
\end{abstract}

Keywords : Communication, Communication Knowledge, Hindu Education.

\footnotetext{
${ }^{1}$ Penulis adalah dosen Jurusan Dharma Duta STAHN-TP Palangka Raya
} 


\section{Pendahuluan}

Pendidikan agama di Indonesia baik yang bersifat formal maupun non formal sesuai dengan sila pertama dari Pancasila yang berbunyi Ketuhanan Yang Maha Esa. Pendidikan agama ini diberikan melalui sistem komunikasi langsung dan tak langsung dengan mempergunakan berbagai media massa, begitu pula dengan pendidikan Agama Hindu yang juga mempergunakan berbagai media massa sebagai sarana komunikasi dalam meyampaikan ajaranajaran Agama Hindu.

Manusia sejak dilahirkan kemuka bumi ini sudah memiliki kemampuan utuk berkomunikasi. Kemampuannya itu semakin hari semakin maju pesat sehingga manusia yang satu dengan manusia yang lainnya dapat memahami keinginan lawan bicaranya. Seseorang yang tuna wicara di dalam berkomunikasi dengan orang-orang disekitarnya tidaklah sama dengan orang yang normal yang mampu mengeluarkan suara dari mulutnya dan menyampaikan keinginan mereka melalui suaranya. Seseorang yang tuna wicara ini mempergunakan tangannya untuk berbicara dengan cara memberikan isyarat ataupun kode dan lambang dalam menyampaikan keinginan-keinginannya. Cara yang dilakukan orang-orang yang tuna wicara ini disebut sebagai bahasa isyarat.

Komunikasi yang sudah ada sejak alam semesta ini ada dan manusia ada didalamya, semakin hari semakin berkembang. Komunikasi juga berjalan beriringan dengan adanya bahasa. Jika kita di Indonesia, kita berkomunikasi dengan mempergunakan bahasa Indonesia, maka orang Jepang, berkomunikasi dengan bahasa Jepang, begitu juga dengan orang-orang yang berada di belahan bumi lainnya. Komunikasi sangat menarik untuk dipelajari, karena menyangkut apa yang kita lakukan sehari-hari, yaitu berbicara dengan mempergunakan bahasa yang sesuai dimana tempat kita berdomisili serta kebiasaan-kebiasaan yang kita lakukan dalam berkomunikasi.

Para ahli komunikasi sejak puluhan tahun lalu selalu saja bisa menemukan teori-teori baru dalam komunikasi sehingga akhirnya di jadikan sebuah ilmu untuk di ketahui masyarakat. Salah satu bagian dari ilmu komunikasi yang sangat penting yaitu retorika.

Retorika secara umum diartikan sebagai seni berbicara. Retorika untuk pertamakalinya dikenal pada abad kelima sebagai suatu ilmu yang mengkaji proses pernyataan antarmanusia sebagai fenomena sosial. Ilmu ini dinamakan di dalam bahasa Yunani rhetorike yang dikembangkan di Yunani Purba, pada abad-abad berikutnya dimekarkan di Romawi dengan nama bahasa Latin rhetorika 
sedangkan dalam bahasa Inggris disebut rhetoric dan didalam bahasa Indonesia retorika (Effendy, 2003:2).

Pendidikan Agama Hindu di dalam penyampainnya kepada umat Hindu juga mempergunakan retorika. Di dalam seni berbicara atau retorika seseorang yang menyampaikan pendidikan Agama Hindu kepada umatnya, mampu menarik minat umat Hindu untuk mendengarkan ajaranajaran yang ada di dalam kitab suci Veda, hal ini dilakukan oleh seorang pendididk Agama Hindu di zaman modern dan juga di zaman dahulu.

Di dalam sistem pendidikan Agama Hindu ada di sebut dengan Upanisad, yang secara umum diartikan duduk di dekat yang dalam hal ini adalah duduk di dekat guru kerohanian. Di dalam menyampaikan ajaran Veda sang guru kerohanian pastilah mempergunakan retorika agar para siswa tertarik untuk mempelajari serta memahami isi ajaran kitab-kitab Veda itu. Sang guru kerohanian mampu menguasai pembicaraannya di dalam menyampaikan ajaran Veda dengan mempergunakan ilmu komunikasi.

\section{Pembahasan}

\subsection{Komunikasi dan Ilmu}

\section{Komunikasi}

Kita seringkali mendengar kata komunikasi di dalam percakapan kita sehari-hari. sebagai contoh, seorang Ibu saat membeli sayur bercerita pada kawanya bahwa Pak Lurah akan di demo karena tidak kunjung juga membagikan raskin atau beras miskin yang sudah menumpuk dikelurahan tanpa ada komunikasi dalam bentuk apapun dengan warga. Dari cerita itu dapat penulis jabarkan arah dari komunikasi yang di maksud oleh si Ibu yang bercerita pada kawannya bahwa Pak Lurah yang tidak berkomunikasi dengan warga untuk memberitahukan mengapa raskin itu belum juga dibagikan menyebabkan ia akan didemo, dan seandainya Pak Lurah melakukan komunikasi dengan warganya maka kemungkinan warga tidak akan mendemonya karena warga sudah tahu apa alasan Pak Lurah belum membagikan raskin itu. Di sini kita bisa melihat dalam komunikasi harus ada pesan yang disampaikan antara yang memberi pesan atau di dalam Ilmu komunikasi di sebut komunikator dan orang yang menerima pesan yang di sebut sebagai komunikan, yaitu si Ibu yanag bercerita pada kawannya bertindak sebagai yang memberikan pesan (komunikator) dan si kawan bertindak sebagai penerima pesan (komunikan). Para cendekiawan menyatakan fenomena sosial yang kini dinamakan komunikasi sudah dimulai sejak zamanya Sokrates, Plato, dan Aristoteles (Effendy, 2003:15). Pada masa Aristoteles studi komunikasi 
berkisar pada retorika dalam lingkungan kecil. Sejak adanya revolusi industri dan revolusi teknologi elektronik dan setelah ditemukan kapal api, pesawat terbang, listrik, telepon, surat kabar, film, radio, televisi, dan lain sebagainya, maka para cendikiawan pada abad sekarang menyadari pentingnya komunikasi ditingkatkan dari pengetahuan (knowledge) menjadi ilmu ( science) (Effendy, 2011:9). Sebelum masuk kedalam ilmu pengetahuan, ada baiknya kita mengetahui apa yang dimaksud dengan komunikasi menurut beberapa pakar komunikasi.

Menurut Suwardi (1986:13) dalam Rohim (2009:8), menyatakan bahwa komunikasi atau di dalam bahasa Inggris communication berasal dari bahasa Latin communis atau dalam bahasa Inggris commun, yang artinya sama. Hal ini senada dengan pernyataan dari Cherry dalam Stuart, 1983 dalam Cangara, 2009:18, Cherry menyatakan bahwa istilah komunikasi berasal pada perkataan Latin communis yang artinya membuat kebersamaan atau membangun kebersamaan antara dua orang atau lebih. Komunikasi juga berasal dari akar kata dalam bahasa Latin communico yang artinya membagi. Moor, 1993: 78 dalam Rohim, 2009:8, mengatakan bahwa komunikasi adalah penyampaian pengertian antarindividu. Dikatakannya semua manusia dilandasi kapasitas untuk menyampaikan maksud, hasrat, perasaan, pengetahuan dan pengalaman dari orang yang satu kepada orang yang lainnya.

Untuk lebih jelasnya apa sebenarnya yang di maksud dengan komunikasi, ada beberapa pendapat para pakar komunikasi yang diantaranya, menurut Edward Depari yang fokus pada komunikasi dalam organisasi, mengatakan komunikasi adalah proses penyampaian gagasan, harapan, dan pesan yang disampaikan melalui lambang tertentu, mengandung arti, dilakukan oleh penyampai pesan ditujukan kepada penerima pesan (Widjaja, 2000:13), Lalu dilanjutkan oleh pendapat dari Hovland, Janis dan Kelly, yang mendefinisikan komunikasi sebagai berikut "communication is the process by which an individual (the communicator) transmits stimuli (ussually verbal symbols) to modify the behavior of the individuals (the audiences)" (Tamburaka, 2012:7).

Kemudian Wiliam F. Glueck yang memfokuskan pendapatnya pada management. Beliau menyatakan bahwa komunikasi dapat dibagi menjadi dua bagian utama, yaitu yang pertama interpersonal communications, artinya proses pertukaran informasi serta pemindahan pengertian antara dua orang atau lebih di dalam kelompok kecil $m$ anusia. Bagian kedua yaitu organization communications, artinya 
dimana pembicara secara sistematis memberikan informasi dan memindahkan pengertian kepada orang banyak di dalam organisasi dan kepada pribadi-pribadi dan lembaga-lembaga yang berhubungan (Widjaja, 2000:14). Ada juga pendapat dari William Albig, yang menyatakan bahwa komunikasi adalah proses pengoperan lambanglambang yang berarti bagi individuindividu(Widjaja, 2000:15).

Selanjutnya pengertian komunikasi menurut Harold Laswell, menyatakan bahwa komunikasi merupakan proses penyampaian pesan oleh komunikator kepada komunikan melalui media yang menimbulkan efek (akibat) tertentu, serta pendapat dari Willbur Schramm yang mengatakan bahwa komunikasi selalu menghendaki adanya paling sedikit tiga unsur, yaitu: sumber (source), pesan (message), dan sasaran ( destination) (Tamburaka, 2012:7).

Sir Geral Barry menyatkan bahwa berkomunikasi adalah berunding, bahwa dengan berkomunikasi orang memperoleh pengetahuan, informasi, dan pengalaman karena itu saling mengerti percakapan, keyakinan, kepercayaan, dan kontrol sangat diperlukan (Widjaja, 2000:15). Judy C. Pearson dan Paul E. Nelson mengemukakan bahwa komunikasi mempunyai dua fungsi umum. Pertama, untuk kelangsungan hidup diri- sendiri yang meliputi : keselamatan fisik, meningkatkan kesadaran pribadi, menampilkan diri kita sendiri kepada orang lain dan mencapai ambisi pribadi. Kedua, untuk kelangsungan hidup masyarakat, tepatnya untuk memperbaiki hubungan sosial dan mengembangkan keberadaan suatu masyarakat (Mulyana, 2011:5).

Menurut Carl I. Hovland dalam Effendy, 2011:10, ilmu komunikasi adalah upaya yang sistemastis untuk merumuskan secara tegas asas-asas penyampaian informasi serta pembentukan pendapat dan sikap. Rohim, 2009:27 dalam bukunya yang berjudul Teori Komunikasi Perspektif, Ragam dan Aplikasi, meyatakan bahwa ilmu komunikasi merupakan salah satu ilmu pengetahuan yang bersifat multidisipliner. Itu terjadi karena ilmu komunikasi berkembang melalui beberapa pendekatan seperti pendekatan yang berasal dari ilmu sosiologi, psikologi, politik, linguistik, antropologi, dan lainnya.

Komunikasi sebagai akar dari ilmu komunikasi merasuk kedalam bidang-bidang ilmu lainnya. Ilmu komunikasi, apabila diaplikasikan secara benar akan mampu mencegah dan menghilangkan konflik antarpribadi, antarkelompok, antarsuku, antarbangsa, dan antarras, membina kesatuan dan persatuan umat manusia dimuka bumi ini (Effendy, 2003:27). 
Cangara, 2009: 65-66 di dalam bukunya yang berjudul Pengantar Ilmu Komunikasi, menyatakan bahwa, komunikasi dalam proses pertumbuhannya merupakan studi retorika dan jurnalistik yang banyak berkaiatan dengan pembentukan pendapat umum. Di dalam peta Ilmu pengetahuan, komunikasi dinilai oleh banyak pihak sebagai ilmu yang monodisiplin yang berinduk pada ilmu politik. Namun dengan perkembangan masyarakat yang begitu cepat, terutama kemajuan di bidang genetika dan teknologi komunikasi maupun di bidang-bidang lainnya telah membawa dampak makin kaburnya batas-batas kewenangan dan fungsi beberapa ilmu pengetahuan, sehingga ilmu yang tadinya monodisiplin cenderung multidisiplin. Begitu juga dengan ilmu komunikasi yang dulunya dikatakan sebagai ilmu yang monodisiplin kini dengan perkembangan dalam proses akumulasi dalam lingkungan ilmu komunikasi itu sendiri dan karena makin integratifnya antara ilmu yang satu dengan yang lainnya, akhirnya ilmu komunikasi yang tadinya diidentikkan sama dengan ilmu pers sebagai bagian dari ilmu politik (monodisiplin) mengalami perkembangan sebagai ilmu yang tidak saja memfokuskan diri pada aspek-aspek kekuasaan di bidang politik dan pemerinthan, tetapi komunikasi dalam arti luas makin dirasakan menyentuh semua aspek kehidupan umat manusia dalam bermasyarakat, seperti berbentuk ilmu ekonomi, hubungan antar bangsa, kekuasaan, organisasi dan perencanaan, penerangan dan penyuluhan, serta dalam tata hubungan antarmanusia itu sendiri. Dikarenakan ilmu komunikasi yang kini merupakan ilmu yang multidisiplin sehingga mampu masuk kedalam bidang ilmu apapun, maka dapat penulis katakan bahwa ilmu komunikasi masuk juga dalam ilmu Agama yang khususnya ilmu Agama Hindu yang berisikan pendidikan Agama Hindu bagi umat Hindu dimanapun mereka berada. Dalam hal ini pendidikan Agama Hindu yang masuk kedalam ruang hidup masyarakat melalui jalur ilmu komunikasi yang berbentuk penerangan dan penyuluhan. Pendidikan Agama Hindu melalui ilmu komunikasi dapat dilakukan oleh siapa saja dan dimana saja.

Sebagai contoh,. Seorang Ayah mengajarkan nilai-nilai dari pendidikan Agama Hindu kepada anaknya dengan berkomunikasi aktif setiap hari dengan anaknya, mengajarkan pelafalan doad o a A g m a $\mathrm{Hind} \mathrm{u} \mathrm{y} \mathrm{a} \mathrm{g}$ mempergunakan bahasa sanskerta, sehingga anaknya mampu melantunkan doa-doa itu dan mempergunakanya dalam kehidupan mereka sehari-hari. $\mathrm{P}$ endidikan Agama Hindu dapat dilakukan oleh guru Agama Hindu dari 
tingkat TK hingga SMU dan diberikan di sekolah formal milik pemerintah amupun swasta serta sekolah non formal seperti pasraman maupun pertemuanpertemuan lain di luar jam sekolah. Begitu pula pendidikan Agama Hindu melalui ilmu komunikasi dapat dilakukan oleh para Tokoh Agama dan juru penerang atau penyuluh yang sering disebut sebagi Dharma Duta yang secara umum diartikan sebagai pembawa kebenaran (dharma), dalam hal ini kebenaran atau dharma yang dimaksud yaitu kebenaran tentang ajaran Agama Hindu yang di sampaikan melalui pertemuan-pertemuan di Pura atau Balai Basarah serta melalui media massa, baik itu media massa cetak seperti, koran, buku, majalah dan tabloid serta media massa elektronik seperti radio dan televisi dan media massa online denga sarana jaringan internet denga mempergunakan perangkat komputer, laptop dan telepon genggam (Hand Phone).

2.2. Nilai Komunikasi Ajaran Vedanta di dalam Pendidikan Agama Hindu

Di dalam sistem pendidikan Agama Hindu pada masa turunnya kitab Veda, kita mengenal adanya Upanisad. Istilah Upanisad berasal dari tiga kata, yaitu Upa berarti dekat, $N i$ berarti di bawah dan Sad berarti duduk. Kata Upanisad berarti : duduk di bawah dekat (acarya) atau guru kerohanian (Titib, 1994 : 7). Kitab Upanisad pada dasarnya membahas Brahman, Atman, Maya dan Avidya. Upanisad menyusun bagian kesimpulan Veda, Upanisad juga disebut Vedanta atau Veda yang terakhir dan memiliki kebijaksanaan tertinggi.

Nilai-nilai komunikasi di dalam ajaran Upanisad sebagai salah satu Vedanta dapat kita lihat dalam penjabaran tentang Vedanta dari seorang Svami Vivekananda, yang mengatakan bahwa Vedanta menyatakan bahwa manusia itu illahi, dalam hal ini yang dimaksud illahi oleh Svami Vivekananda adalah Brahman, dimana semua yang kita lihat disekitar kita ini adalah hasil dari kesadaran illahi.

Segala hal yang baik, kuat, ampuh, dalam sifat manusia berasal dari keillahian itu, dan walaupun berpotensi dalam banyak hal, pada dasarnya tak ada perbedaan antara manusia satu dengan manusia lainnya, dimana esensialnya semua mahluk adalah illahi. Vedanta menekankan bahwa setiap orang harus diperlakukan sama, bukan karena penampilannya, namun sebagai lambang apa dia itu. Setiap manusia merupakan perwujudan keilahian, sehingga setiap guru harus menjadi penolong, bukan hanya menyalahkan orang, namun dengan membantunya menyadari keilllahian yang dimilikinya. Kumpulan energi yang kita lihat diperagakan dalam masyarakat, dalam 
setiap bidang kegiatan, sesungguhnya berasal dari dalam keluar,sehingga apa yang disebut inspirasi oleh sekte lain, kaum Vedantin dengan bebas menyebutnya ekspresi manusia. Vedanta tak mempermasalahkan mereka yang tak memahami keilahian manusia. Secara sadar ataupun tidak sadar setiap orang berusaha untuk menyingkap keillahan itu. Pemikiran istimewa lain dari Vedanta adalah bahwa kita harus mengijinkan keberagaman tak terbatas dalam pemikian religius dan tidak berusaha untuk membawa seseorang pada pendapat yang sama, karena tujuannya adalah sama (Vivekananda, 2006 :18-19 dan 21).

Vedanta mampu membuat seorang Svami Vivekananda menyampaikan ajaran Hindu di negaranegara Barat dan memberikan pemahaman-pemahaman baru didalamnya. Salah satu bagian dari Vedanta yaitu Bhagawad Gita yang berisikan percakapan antara Sri Krisnhna dan Arjuna di medan perang Kuruksetre. Sri Krishna banyak memberikan wejangan kepada Arjuna yang selanjutnya dijadikan pedoman sehari-hari dalam bertindak oleh umat Hindu.

Narayana (2010: 67-69) menguraikan bahwa di dalam Bhagawad Gita ada di katakan tentang percakapan Sri Krishna dan Arjuna tentang hal pengendalian lidah dalam makan dan bicara. Bhagawad Gita menandaskan perlunya bersikap sangat hati-hati bila memilih makanan yang engkau makan. Engkau harus selalu ingat pentingnya makanan yang satwa untuk membantu menjaga kesimbangangan batin dalam segala situasi sehingga engkau tidak berbesar hati bila dipuji atau berkecil hati bila dicela. Karena itu, sebelum engkau makan, engkau harus berdoa dan mempersembahkan seluruh makanan kepada Tuhan agar dibersihkan dan disucikan. Doa sebelum makan dapat kita ambil dari Bhagawad Gita (IV. 24 dan 14 ).

Brahmaarpanam, Brahma Havir, Brahmaagnau Brahmanaa

Hutam,

Brahmaiva Tena Gantavyam, Brahma Karma Samaadhinaha Aham Vaishvaanaro Bhutvaa, Praaninaam Dehamaashritaha Praanaapaana Samaa Yuktaha, Pachaamy Annam Chatur Vidham

Terjemahan :

Upacara persembahan adalah Brahman, persembahan itu sendiri adalah Brahman, dipersembahkan oleh Brahman dalam api suci yang juga Brahman. Hanya dialah mencapai Brahman yang dalam seluruh kegiatannya khusyuk sepenuhnya dalam Brahman. Aku Adalah Waishwaanaro, kemampuan yang memenuhi alam semesta yang berada dalam badan segala makhluk hidup. Menyatu dengan nafas yang masuk dan keluar, Aku mencerna segala macam (empat jenis) makanan. 
Menurut Bhagawad Gita, memgendalikan lidah dengan makan makanan yang satwik secara terbatas, sangat penting bagi seorang manusia. Aspek kemampuan lidah yang kedua adalah bicara. Perkataan mempunyai pengaruh yang kuat pada pikiran dan seluruh proses mental. Pengaruhnya sangat hebat. Ia bisa memotong pikiran, ia bisa menghancurkan hatimu bahkan dapat membunuhmu. Tetapi ia juga dapat memberikan kehidupan, semangat, dan membantu engkau mencapai tujuan. Dua akibat yang bertentangan ini ditimbulkan oleh katakata yang kauucapkan. Dengan menggunakan kata-kata yang tepat, engakau dapat mengubah pikiran seseorang. Jadi kita sebagi manusia berkomunikasi di dalam kehidupan kita dengan berkata-kata di pengaruhi oleh makanan yang kita makan dan juga berpengaruh pada pikiran kita.

Setiap manusia yang hidup di dunia ini melaksanakan kegiatannya sehari-hari berdasarkan karmanya masing-masing. Begitu pula dengan Arjuna di medan perang yang telah terlibat perang saudara dan Arjuna merasa ragu maju di medan perang itu. Namun Sri Krishna berusaha memberikan pemaham-pemahaman pada Arjuna dengan terus berkomunikasi dengannya. Wejangan Sri Krishna ini dapat dilihat dalam Bhagawad Gita bab XVI. 24, yang bunyinya sebagai berikut :

Tasmac chastram pramanam te , Karyakarya vyavasthitau, Jnatva sastra vidhanoktam, Karma kartum iharhasi.

Terjemahan :

Karena itu, seharusnya seseorang mengerti apa itu kewajiban dan apa yang bukan kewajiban menurut peraturan Kitab Suci. Dengan mengetahui aturan dan peraturan tersebut, hendaknya ia bertindak dengan cara supaya berangsur-angsur dirinya maju ke tingkat yang lebih tinggi.

Pendit (1993:36-37) menguraikan karma harus dilaksanakan dalam semangat pengabdian kepada Tuhan. Sri Krishna pun berkata pada Arjuna "engkau adalah kesatria. Bertempur adalah karma ksatria yang telah ditetapkan. Dari sini kiranya kelihatan bahwa pokok-pokok ajaran Sri Krihna adalah pelaksanaan karma.

Lokamaya Bal Gangadhar Tilak telah merumuskan bahwa Bhagawadgita adalah merupakan kitab suci penuntun kerja. Kata-kata Sri Krishnapun agaknya membenarkan pandangan tafsiran ini. Sri Krishna berulang-ulang berkata “ Bertempurlah, itulah dharmamu. Setiap orang harus menepati dan berpegang pada dharmanya sendiri. Svakarmana tamabhyarchya, yang artinya dengan jalan menyembah Dia melaksanakan kerja sendiri. Yajnarthat karmano nyatra, loko yam karma bandhanah, yang artinya kecuali untuk tujuan 
berbakti dunia ini dibelenggu oleh hukum kerja. Perkataan yajna disini diartikan sebagai Batara Wisnu sendiri, Paramatman yang tertinggi. Yajna juga dapat diartikan sebagai bhakti persembahan. Laksanakan karmamu degan kesadaran bahwa Tuhan ada, dan baktikanlah apa yang engkau kerjakan kepada-Nya.

Sri Krsihna juga berkomunikasi dengan Arjuna dan tertuang dalam Bhagawadgita tentang betapa besarnya kekuatan dari doa dengan cara melakukan pengulangan nama Tuhan (japayajna). Disaat seseorang melantunkan doa atau kidung suci dengan suara yang nyaring dan merdu, maka orang -orang disekitarnya akan tertarik untuk ikut memuja dan berdoa pada Tuhan (Sandika, 2011: 33). Di sini kita dapat melihat pelantun kidung pertama (komunikator) berusaha menyampaikan pesan lewat kidung atau doa untuk Tuhan kepada orang (komunikan) disekitarnya.

Dari berbagai macam percakapan antara Sri Krishna dengan Arjuna dalam Bhagawadgita dapat kita lihat nilai-nilai komunikasi mereka untuk pendidikan bagi umat Hindu. Semua proses hidup dan kehidupan ini berawal dan berakhir sesuai dengan karma kita masingmasing sebagai makhluk hidup ciptan Tuhan. Selain karma sebagai intinya hidup di dunia ini ada juga Bhakti dan Yoga. Ajaran didalam Bhagawadgita diharapakan mampu menuntun umat manusi kejalan yang lebih baik dalam berkata, bertindak serta berpikir.

\section{Penutup}

Ilmu komunikasi di dalam pendidikan Agama Hindu sangatlah penting, karena dengan berkomunikasi yang baik maka ajaran-ajaran yang ada di dalam kitab-kitab suci Agama Hindu bisa tersampaikan dengan baik kepada umat Hindu dimanapun mereka berada. Dengan berkomunikasi seseorang dapat menyampaikan ide serta saran ataupun kritikannya bagi kemajuan umat Hindu itu sendiri. Pendidikan Agama Hindu diberikan oleh siapapun yang mau membagikan ilmunya pada orang lain. Agama Hindu tidak hanya diberikan di dalam pendidikan yang bersifat formal namun juga dalam pendidikan yang bersifat non formal. Semua orang berhak menafsirkan ajaran-ajaran Agama Hindu sesuai dengan keyakinan dan pemikiran-pemikiran mereka terhadap Tuhan dan para Dewa sebagai sinar suciNya.

\section{DAFTAR PUSTAKA}

Cangara, H. Hafied. 2009. Pengantar Ilmu Komunikasi. Jakarta : Raja Grafindo Persada.

Effendy, OnongUchjana. 2003. Ilmu, Teori, dan Filsafat Komunikasi. Bandung: Citra Aditya Bakti.

Effendy, OnongUchjana. 2011. Komunikasi Teori dan Praktek. 
Bandung: Remaja Rosdakarya.

Mulyana. Deddy, MA.,Ph.D. Prof. 2011. Ilmu Komunikasi Suatu Pengantar. Bandung : PT Remaja Rosdakarya.

Narayana, Swami Sathya Alih Bahasa Sadia I Wayan. 2010 . Melaksanakan Gita Sehari-hari Jalan Menuju Tuhan. Surabaya : Paramita.

Tamburaka, Apriadi. 2012. Agenda Setting Media Massa. Jakarta : PT. Raja Grafindo Persada.

Titib, I Made. 1994.

Pendit, Nyoman S. 1993. Aspek-Aspek Agama Hindu : Seputar Weda dan Kebajikan. Jakarta : Pustaka Manik Geni.

Prabhupada, A.C.Bhaktivedanta Swami. 2000. Bhagavad Gita Menurut Aslinya. Jakarta. Hanuman Sakti.

Rohim, Syaiful. 2009. Teori Komunikasi : Perspektif, Ragam dan Aplikasi. Jakarta: Rineka Cipta.

Sandika, I Ketut. 2011 : Pendidikan Menurut Veda. Denpasar : Pustaka Bali Post.

Vivekananda, Svami diterjemahkan oleh Kamajaya Gede \& Sanjaya Oka. 2006. Vedanta Gema Kebebasan. Surabaya: Paramita.

Widjaja, H.A.W. 2000. Ilmu Komunikasi Pengantar Studi. Jakarta. Rineka Cipta. 
Jurnal Dharma Duta 2017 VOL XV, Januari - Juni 2017 